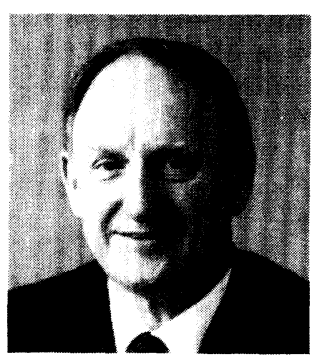

\section{The Conference I Missed}

I had fully intended to participate in a very interesting conference held at Vanderbilt University, March 4-7, 1992. The title of this meeting was "Philosophical, Ethical, and Practical Aspects of Editing Refereed Science Journals-A Workshop for Editors of Refereed Scientific Journals." The workshop cochairs were R. A. Weeks and D. L. Kinser of the Department of Materials Science and Engineering at Vanderbilt University. Dr. Weeks is the editor of the Journal of Non-Crystalline Solids and Dr. Kinser is coeditor.

The organizers had contacted me some time ago (along with other editors) to get our reaction to such a conference. I told them I thought it was a good idea and that I would be pleased to participate and prepare a contributed paper entitled "Editing in the applied sciences."

But as the much quoted Robert Burns said "The best laid schemes o' mice an' men gang aft a-gley." For reasons beyond my control (I was ill), I did not make the meeting, but sent my paper anyway. My modest contribution will appear in the proceedings to be published later this year. The words of Burns again come to mind:

But human bodies are sic fools,

For a' their colleges and schools,

That when nae real ills perplex them,

They make enow themsels to vex them.

I am not sure that there are any "real ills" to perplex us in the editorial process, but I do believe that we may "make enow" ourselves to vex us. Issues exist that editors do have to be concerned about, and a conference of this kind is a good forum for discussing them. It is worth quoting here some of the philosophy behind the meeting as set out in the brochure describing the meeting:

The workshop will consist of invited talks, contributed papers, and discussions. These will articulate the justifications for refereed science journals, ethical principles of editors and publishers, and practical aspects of refereeing, of editing, and of publishing such journals. Conventional wisdom is that refereed science journals are the sine quo non of reputable research suitable for dissemination to the general public.
The reports of research published in these journals are, in this conventional wisdom, reports of the best research. This workshop will consider whether this wisdom has a basis in fact and how the actions of editors ensure that such is the case.

Recent stories in newspapers and such journals as Science, hearings by congressional committees, and actions by federal agencies to establish procedures by which allegations of author malfeasance may be determined are evidence that there are problems with the functioning of referees and editors. There are no established procedures for most journals by which a paper containing false data can be retracted. There are few reliable methods for determining if a paper has had multiple publications. The criteria for multiple publications are ambiguous. Editorial biases are rarely discussed. The power of an editor to select referees who will reject a paper is under no control, nor are there generally accepted guidelines. The failures of the system of refereeing have been discussed in books and in some conferences. Few suggestions for improving the system have been made. Responsibilities and ethics of editors have rarely been publicly discussed. This conference will consider these and many other problems that beset editors of refereed science journals from the United States, Europe, USSR, Japan, and many other countries.

Again, I am sorry that I missed direct participation in this workshop, but I certainly look forward to reading the words of my fellow editors from such journals as Science, Journal of the American Chemical Society, Philosophical Magazine, Human Pathology, Journal of the American Medical Association, Proceedings of the IEEE, and the Journal of Physics and Chemistry of Glasses (USSR).

I will certainly let you know when the volume is published.

Brian J. Thompson Editor 
June 1992

Adaptive Signal Processing

Simon Haykin

McMaster University

Communications Research Laboratory

1280 Main Street West

Hamilton, Ontario L8S 4K1 Canada

416/525-9140

\section{August 1992}

Optical Engineering and U.K. Industry

Lionel R. Baker

Sira Ltd.

South Hill, Chislehurst

Kent BR7 5EH, United Kingdom

+44814672636 • +4481467 6515 FAX

R. J. Parker

Rolls Royce plc

P.O. Box 31

Derby DE2 8BJ, United Kingdom

\section{September 1992}

Wavelet Transform

Harold H. Szu

U.S. Navy

Naval Surface Warfare Center, Code R44

10901 New Hampshire Ave.

Silver Spring, MD 20903-5000

301/394-3097 • 301/394-3923 FAX

October 1992

Acousto-Optics

Ting-Chung Poon

Virginia Polytechnic Institute and State University

Bradley Department of Electrical Engineering

Optical Image Processing Laboratory

Blacksburg, VA 24061

703/231-4876 • 703/231-3362 FAX

November 1992

Relay Mirror Experiment

Paul W. Kervin

Phillips Laboratory

535 Lipoa Parkway, Suite 200

Kihei, HI 96753

808/874-1542 • 808/874-1640 FAX

\section{December 1992}

\section{Automatic Target Recognition}

Firooz Sadjadi

Systems and Research Center

Honeywell Inc.

3660 Technology Drive

Minneapolis, MN 55418

$612 / 782-7543 \cdot 612 / 782-7438 \mathrm{FAX}$

\section{January 1993}

\section{Optical Research in Asia}

Chung J. Kuo

National Chung Cheng University

Department of Electrical Engineering

Chiayi, Taiwan 62107

886-5-272-0411, ext. 6210 • 886-5-272-0862 FAX

Toshimitsu Asakura

Hokkaido University

Research Institute of Applied Electricity

Sapporo, 060 Japan

81-11-716-2111 - 81-11-758-3173 FAX
Yong H. Lee

KAIST Department of Physics

Yusung-Ku, Taejon, Korea

82-42-829-2536 - 82-42-861-1458 FAX

Run W. Wang

Shanghai Institute of Optics and Fine Mechanics

P.O. Box 800-211

Shanghai, 201800 China

\section{February 1993}

\section{Biomedical Optics}

Abraham Katzir

Tel Aviv University

School of Physics

$69978 \mathrm{Tel}$ Aviv, Israel

011-972-3-421648 • 011-972-3-415850 FAX

Manuscripts due June 15, 1992.

March 1993

Optical Fiber Reliability II

Hakan H. Yuce

Bellcore

445 South Street

Morristown, NJ 07962

201/829-4945 - 201/267-9753 FAX

Charles R. Kurkjian

AT\&T Bell Laboratories

600 Mountain Avenue

Murray Hill, NJ 07960-1910

908/582-2378 • 908/582-2783 FAX

Manuscripts due July 15, 1992.

\section{April 1993}

Emerging Optoelectronic Technologies

Vijai K. Tripathi

Oregon State Univeristy

Dept. of Electrical and Computer Eng.

ECE Building 220

Corvallis, Oregon 97331-3211

$503 / 737-3617 \cdot 503 / 737-1300 \mathrm{FAX}$

Manuscripts due Sep. 1, 1992

May 1993

Phase Contrast Microscopy

Maksymilian Pluta

Institute of Applied Optics

ul. Kamionkowska 18

03-805 Warszawa, Poland

4822184405 or 4822184497

4822133265 FAX

This special issue is connected with an international conference on Phase Contrast $(P h C)$ and Differential Interference Contrast Microscopy, scheduled Oct. 19-21, 1992, in Warsaw, Poland, and organized by the Polish Chapter of SPIE. Topics will include theory and practice of phase micro-objects visualization, instrumentation for $P h C$ microscopy, quantitative $P$ hC techniques, linear phase microscopy, laser scanning differential PhC microscopy, scanning tunneling microscopy of phase objects, and new applications in biology/biomedicine and materials sciences. Manuscripts due Oct. 1, 1992.

\section{June 1993}

From Numerical to Symbolic Image Processing: Systems \& Applications

G. Vernazza

Dipartimento di Ingegneria Biofisica ed Elettronica Universita degli Studi di Genova

Via Opera Pia, 11a

16145 Genova, Italy

+3910 353-2755 - +39 10 353-2777 FAX
This special issue will present innovative research and results on the integration between numerical and symbolic processing. Examples covering real applications will be considered. Manuscripts due Oct. 15, 1992.

\section{July 1993}

Visual Communication and Image

Processing IV

Cheng-Tie Chen

Bellcore

445 South St.

Morristown, NJ 07962

201/829-5151 - 201/829-5884 FAX

Hsueh-Ming Hang

Center for Telecommunication Research

National Chiao-Tung University

Hsinchu, Taiwan

$+886 / 35-712121 \times 3298 \bullet+886 / 35-723283$ FAX

Kou-Hu Tzou

COMSAT Labs.

22300 Comsat Drive

Clarksburg, MD 20871

301/428-4663 - 301/428-7747 FAX

Papers in this special issue will include, but are not limited to, the following topics: visual communication services, systems, and standards; image compression algorithms for binary, still, and motion pictures; advanced and high-definition TV; video networking; model-based image coding; image segmentation and understanding; pattern recognition; human visual models for image processing; image processing for medical applications; and imaging technology. Manuscripts due Dec. 1, 1992.

\section{September 1993}

Optical Science and Engineering in Canada

\section{C.P. Grover}

National Research Council

Institute for National Measurement Standards

Ottawa, Canada K1A OR6

613/993-2098 • 613/952-1394 FAX

Manuscripts due Feb. 1, 1993.

October 1993

Microlithography

James R. Sheats

Hewlett-Packard Company

2500 Deer Creek Road

Palo Alto, CA 94304-1392

415/857-5987 • 415/857-6241 FAX

This issue will cover the range of topics found in the SPIE Symposium on Microlithography (San Jose, Calif.), including resist materials, optical systems, and metrology. Manuscripts due March $1,1993$.

\section{November 1993}

Acquisition, Tracking, and Pointing

Mohammed A. Karim

University of Dayton

Center for Electro-Optics

300 College Park

Dayton, Ohio 45469-0227

$513 / 229-2241 \cdot 513 / 229-3433$

Manuscripts due April 1, 1993. 